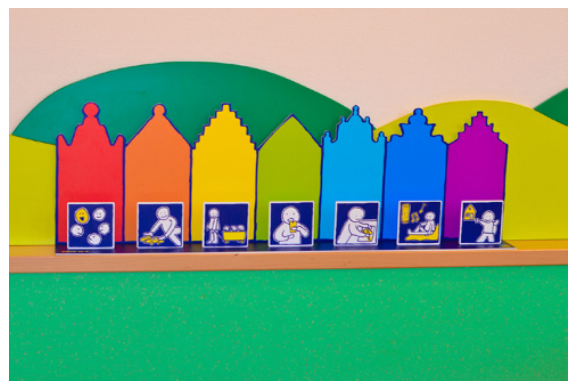

\section{Kleurrijk dagprogramma}

Blinkstreet is een herkenbaar hulpmiddel bij het dagprogramma. Het is gemaakt in de vorm van een straat met zeven gekleurde huisjes. Op ieder stoepje staat een plaatje dat naar een activiteit verwijst. Het is een duidelijk systeem, dat kinderen structuur biedt en helpt om het dagprogramma te begrijpen. Ook aanbevolen voor kinderen met bijvoorbeeld een taalontwikkelingsstoornis. Er is ook een kleine versie, voor één kind: Blinkstreet Small. Prijs: €49,95 (small) en €99,95 (large). Verkrijgbaar via: www.geefmede5.nl.

\section{BoekStartapp}

De nieuwe BoekStartapp staat vol video's en heldere informatie over voorlezen. Ook vind je er de nieuwste boeken- en voorleestips voor baby's, peuters en kleuters. Of stel een voorleeswekker in, die je eraan herinnert om op tijd voor te lezen en nieuwe boeken te halen bij de bibliotheek. BoekStart is het leesbevorderingsprogramma van Stichting Lezen voor baby's en peuters. De app is gratis te downloaden (voor Android en IOS). Kijk voor meer informatie op www.boekstart. nl/boekstart-voorlees-app.

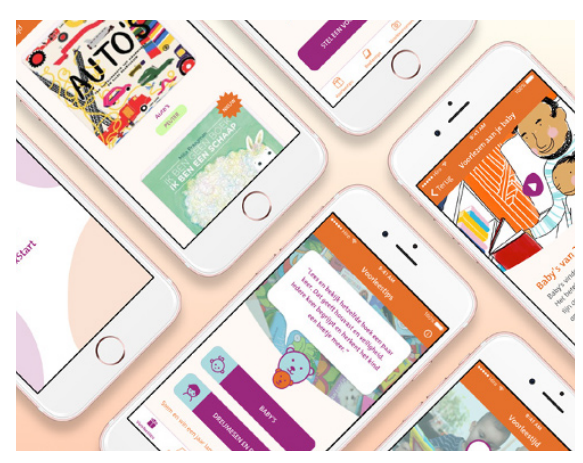

\section{BABYDOEKJES MET 99,9\% WATER}

De babydoekjes WaterWipes bestaan uit slechts twee ingrediënten: 99,9\% water en $0,1 \%$ verzorgend fruitextract. De doekjes bevatten geen chemicaliën en zijn daardoor ook geschikt voor de gevoelige babyhuid. Ze kunnen meteen vanaf de geboorte worden gebruikt. Een pak kost $€ 3,99$, maar er zijn ook voordeelverpakkingen verkrijgbaar. Meer informatie: www.waterwipes.nl

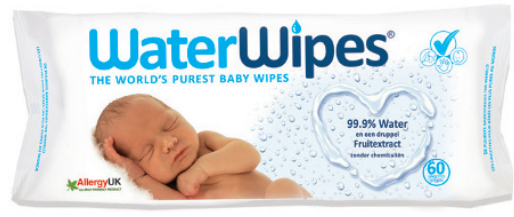

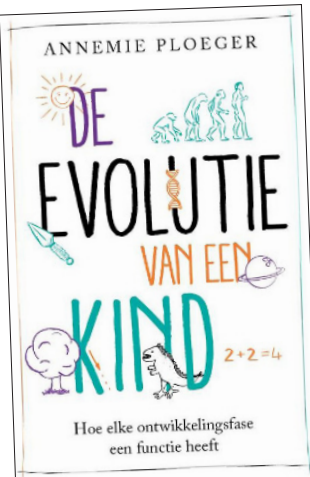

\section{De evolutie}

\section{van een kind}

Waarom huilen baby's vaak en hebben peuters driftbuien? Waar komen sekseverschillen vandaan? In het boek De evolutie van een kind beschrijft evolutionair-ontwikkelingspsycholoog Annemie Ploeger op een laagdrempelige manier de ontwikkelingsfases van het kind, van de bevruchting tot aan de volwassenheid. Verkrijgbaar bij de (online) boekenwinkel. Prijs: € 22,95.

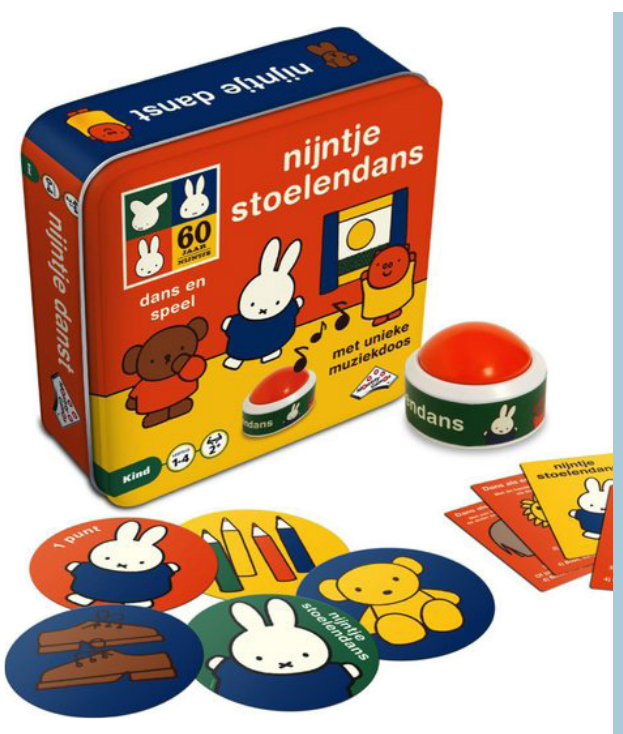

\section{Stoelendans met Nijntje}

Het vrolijke dansspel nijntje stoelendans bevat een muziekdoos die liedjes speelt. Druk op de knop om de muziek te laten spelen en pak een dansopdracht. Dans met de kinderen op de danscirkels die op de grond liggen, tot de muziek stopt. Wat staat er op het plaatje? Het spel heeft verschillende niveaus en is leuk voor kinderen tot en met vier jaar oud. Prijs: $€ 15,99$.

\title{
BINNEN VOETBA느N
}

Met het Kick \& Stick voetbalspel wordt binnen voetballen leuk, en veilig! Met de set maak je met dubbelzijdige tape twee goals op de muur. De bal is zacht, maar sterk genoeg om mee te voetballen. Het spel maakt geen geluid en is veilig voor anderen en het meubilair. Wel zo prettig! Verkrijgbaar via www. heutink.nl. Prijs: $€ 19,95$.
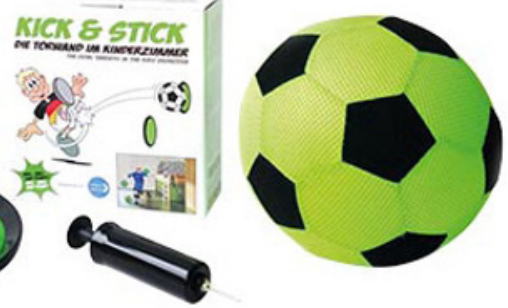